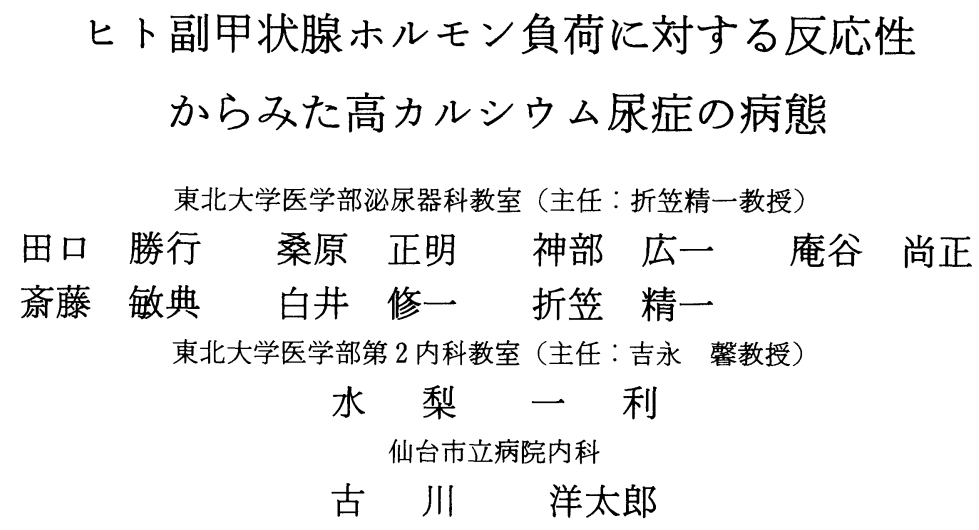

\title{
THE PATHOGENESIS OF HYPERCALCIURIA FROM THE ASPECT OF THE RESPONSE TO HUMAN PARATHYROID HORMONE IN Ca CONTAINING STONE FORMERS
}

\author{
Katsuyuki Taguchi, Masa-aki Kuwahara, Kouichi Kambe, Naomasa Ioritani, \\ Toshinori Saitoh, Syuichi Shirai and Seiichi Orikasa \\ Department of Urology, Tohoku University School of Medicine \\ (Director: Prof. Seiichi Orikasa) \\ Kazutoshi Mizunashi \\ Second Department of Internal Medicine, Tohoku University School of Medicine \\ (Director: Prof. Kaoru Yoshinaga) \\ Yohtaro Furukawa \\ Department of Internal Medicine, Sendai City Hospital
}

In order to clarify the pathogenesis of hypercalciuria, the response to extrinsic human parathyroid hormone (h-PTH) was studied the 21 patients with calcium containing urinary stone(s) and 5 normal controls (NO). The stone patients were classified into 3 groups from the result of the oral calciumloading test, i.e. Non-hypercalciuria $(\mathrm{NH}, \mathrm{n}=8)$ and absorptive hypercalciuria $(\mathrm{AH}, \mathrm{n}=8)$ and renal hypercalciuria $(\mathrm{RH}, \mathrm{n}=5)$.

Only in the AH group, urinary excretion of calcium ( $\mathrm{u}-\mathrm{Ca}$ ) was strongly correlated to that of sodium (u-Na) in pre-load of h-PTH, and both increments were also correlated in post-load of h-PTH. As of this fact the increase in $\mathrm{Na}$ excretion seems to be responsible for a cause of hypercalciuria in the $\mathrm{AH}$ group.

There was a significant correlation between the value of \%TRP in pre-load of $h$-PTH and the rate of urinary phosphorus $(\mathrm{P})$ increment between pre-load and post-load of h-PTH in the NO and NH groups. However, this relationship was not found in the $\mathrm{AH}$ and $\mathrm{RH}$ groups. These findings indicate that there is response disorder of $\mathrm{P}$ to h-PTH. In addition, serum $\mathrm{P}$ was low, plasma $1,25(\mathrm{OH})_{2} \mathrm{D}$ was high, N-c-AMP was low in the AH group, whereas both serum P and \%TRP were low in the RH group in pre-load of $h-P T H$. These findings are compatible with the primary renal $P$ leak. The fact that plasma $1,25(\mathrm{OH})_{2} \mathrm{D}$ was not so high and N-c-AMP was not so low in the RH group as compared to those of the $\mathrm{AH}$ group will be explained by the high urinary $\mathrm{Ca}$ excretion.

In conclusion, pathogenesis of hypercalciuria can be explained by a single line of primary renal $\mathrm{P}$ leak, and it seems to exist a continuous pathogenesis between the $\mathrm{AH}$ and $\mathrm{RH}$ groups depending on the amount of renal Ca leak.

Key words: calcium nephrolithiasis, hypercalciuria, parathyroid hormone 
要旨：Ca 含有結石患者21名を正常 $\mathrm{Ca}$ 尿症 ( $\mathrm{NH}$ 群) 8 名, 腸管吸収型高 $\mathrm{Ca}$ 尿症 ( $\mathrm{AH}$ 群) 8 名, 腎漏 出型高 $\mathrm{Ca}$ 尿症 (RH 群) 5 名に分類した後，ヒト副甲状腺ホルモン（h-PTH）を静注し，その反応性か ら高 $\mathrm{Ca}$ 尿症の病態について検討した。対照として正常者（NO 群） 5 名にも施行した.

尿中 $\mathrm{Ca}$ 排泄量と尿中 $\mathrm{Na}$ 排泄量は, h-PTH 負荷前, 負荷後の増加率で $\mathrm{AH}$ 群のみ強い正の相関を示 し, $\mathrm{AH}$ 群に抢ける高 $\mathrm{Ca}$ 尿症の一因として尿中 $\mathrm{Na}$ 排泄量は無視できないと考觉られた。 また, h-PTH 負荷前の\%TRP と負荷後の尿中 P 排泄量の増加率では NO 群, NH 群で有意の相関を認めた。 しかし, 高 $\mathrm{Ca}$ 尿症では明らかな関係を認めず $\mathrm{P}$ の h-PTH 反応性に障害があると考兄られた. 加えて, AH 群で は, h-PTH 負荷前の血中 P が低值を, 血漿 $1,25(\mathrm{OH})_{2} \mathrm{D}$ が高值を, N-c-AMP が低值を示すことから, 一方 RH 群でも，負荷前の血中 $\mathrm{P}$ と\% TRP が低值を示すことから高 Ca 尿症に括ける一次的な $\mathrm{P}$ の漏 出が考光られた。しかし， RH 群では同時に Ca の漏出があるため, $\mathrm{AH}$ 群に比べ $1,25(\mathrm{OH})_{2} \mathrm{D}$ が高值を 示さず，N-c-AMP が低值を示さなかったと考学られる。

すなわち高 $\mathrm{Ca}$ 尿症の原因として, 一次的な $\mathrm{P}$ の漏出があり $\mathrm{Ca}$ 漏出の程度により $\mathrm{AH}$ 群から $\mathrm{RH}$ 群 まで連続的な病態が存在していると考えられた。

キーワード : $\mathrm{Ca}$ 含有結石, 高 $\mathrm{Ca}$ 尿症, 副甲状腺ホルモン

\section{緒言}

尿路結石の約 $90 \%$ 占めるカルシウム（以下 $\mathrm{Ca}$ ) 含 有結石患者では，なんらかの Ca 代謝障害があると考 兄らているが，その本態は不明のことが多い. 現在, 尿中 $\mathrm{Ca}$ 排泄量の点から結石患者を分類した場合，正 常 Ca 尿結石患者（NH 群：Non-hypercalciuric nephrolithiasis), 腸管吸収型高 $\mathrm{Ca}$ 㽷症 (AH 群： Absorptive hypercalciuria), 腎漏出型高 $\mathrm{Ca}$ 尿症 $(\mathrm{RH}$ 群：Renal hypercalciuria）の 3 群に分類するのが一 般的である。しかし，その分類，病態については異

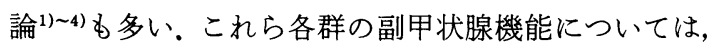
$\mathrm{AH}$ 群で抑制されており， RH 群で充進しているとの 報告5) 8) が多いが, 高 $\mathrm{Ca}$ 㽷症の定義の違いや, 各群で の腎原性 c-AMP や血清 PTH 值が正常域に近い範囲 で変動していることなどから, 各群における副甲状腺 機能の詳細は不明である。今回各群の副甲状腺ホルモ ン(以下 PTH)に対する反応性を検討する目的で, Ca 含有結石患者を $\mathrm{NH}$ 群, $\mathrm{AH}$ 群, RH 群に分類した後, h-PTH の負荷試験を行い, 各群の病態について比較検 討を加光た。

\section{1. 対象}

Ca 含有結石患者21例（男性16名, 女性 5 名) を対象 とした. 年齢は, 男性が 19 歳 61歳, 平均 43.3 歳, 女 性が38〜61歳, 平均40.4歳であった。今回は対照とし て基礎疾患のない健常者 5 名(男 5 名)（以下 NO 群： Normal control)（年龄21 30歳, 平均25歳)について 検討した。自由食下で 1 日尿中 Ca 排泄量が $200 \mathrm{mg} /$ day 以上を示した者に対して, 経ロカルシウム負荷試 験を施行し, 次項 2 及び図 1 でのべる定義に従って次
の 3 群に分類した。

Non-hypercalciuric nephrolithiasis (以下 $\mathrm{NH}$ 群)：8名（男 6 名，女 2 名）

Absorptive hypercalciuria (以下 AH 群)：8名 (男 6 名, 女 2 名)

Renal hypercalciuria (以下 RH 群)：5 名(男 4 名, 女 1名).

いずれの症例も, 尿路結石以外に基礎疾患を認めず, 腎機能も正常であり，血中 $\mathrm{Ca}$ 值は正常範囲である. た，通過障害や明らかな尿路感染症も認めなかった。 $\mathrm{NH}$ 群 8 例は, 再発性, あるいは多発性の $\mathrm{Ca}$ 含有結石 患者であった. c-AMP の検討では $\mathrm{NH}$ 群 7 名, $\mathrm{AH}$ 群 7 名を対象とした。な拓，測定上の問題より，血墏1, $25(\mathrm{OH})_{2} \mathrm{D}$ は, $\mathrm{NH}$ 群 4 名, $\mathrm{AH}$ 群 5 名, RH 群 4 名, NO 群 1 名を対象とした。

\section{2. 経ロカルシウム負荷試験（図 1)}

$\mathrm{Ca}$ 負荷試験の方法は, 孫らの方法 ${ }^{9}$ に準じて施行し た。すなわち，検査前日 $3 \sim 7$ 日間乳製品などの高力 ルシウム含有食の摂取を禁止，少なくとも 12 時間以上 の絶食の後, 9:00a.m. にカルシゥム $1 \mathrm{~g}$ を乳酸カルシ ウムとして服用させた. $7 ： 00$ a.m. 〜 1：00p.m. まで, 2 時間ごとに採尿と各中間時間の採血を 3 回ずつ施行 し, 採尿ごとに水 $300 \mathrm{ml}$ をのませた. $\mathrm{NH}$ 群, $\mathrm{AH}$ 群, $\mathrm{RH}$ 群は, 図 1 に示した表に従い分類した。

\section{PTH 負荷試験（図 2)}

入院の上, Ellsworth-Howard 試験（以下 E-H 試 験 $)^{10)}$ に準じて施行したが, 検査前日は乳製品の摄取を 禁止し, 夕食 $(6: 00$ p.m. $)$ 後は领水のみとして, overnight-fasting の状態で施行した点で標準法と異 
図 1 経ロカルシウム負荷試験の方法と高カルシウム 尿症の分類

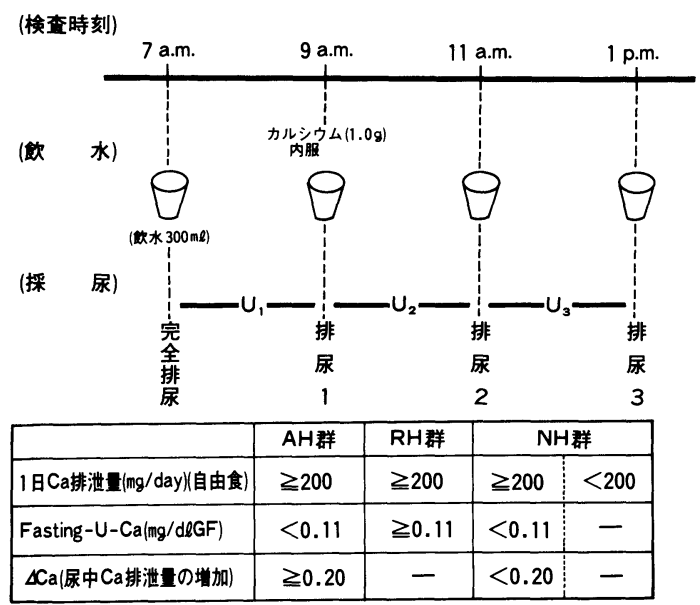

図 2 h-PTH 負荷の方法

(前処 罡)

・模㭗前日は，乳製品摄取制限

・模古当日は，次水のみ

(検去時刻)

(歅 水)

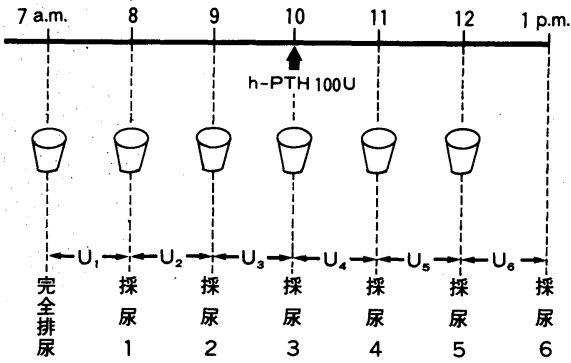

なる. $7 ： 00$ a.m.〜1：00p.m. まで，1時間ごとに採尿 と各中間時間の採血を行い，採尿ごとに水 $200 \mathrm{ml}$ を飲 ませた。 10：00a.m.に，ヒトPTH 100単位を生食 $5 \mathrm{ml}$ に溶解し 5 分かけて静注した. 用いたヒト PTH は, 東 洋釀造社製の, ヒ上副甲状腺ホルモンの $\mathrm{N}$ 末端(1-34) ペプチド製剤 (以下 h-PTH) である. 7：00a.m.〜8： 00a.m. までの尿を U1, 以下順次 U2から U6までとし た。尿中 $\mathrm{Cr}, \mathrm{Ca}, \mathrm{Na}, \mathrm{P}, \mathrm{c}-\mathrm{AMP}$ は, U1 U6で測定 した。血中 Cr，c-AMP は採尿の各中間時間で測定し た。腎原性 c-AMP(以下 N-c-AMP) は尿中 c-AMP 排 泄量から血中 c-AMP を差し引いて求めた。血中 $\mathrm{P}$ は U3の中間時間で, 血中 c-AMP は, PTH 負荷直前と負 荷後 $0,5,10,15,20,30,60$ 分で, 血漿 $1,25(\mathrm{OH})_{2}$ $\mathrm{D}$ は, PTH 負荷直前と負荷後 $3 ， 6 ， 12 ， 24$ 時間でそ れぞれ測定した。
図 3 尿中 $\mathrm{Ca}$ 排泄量の変動

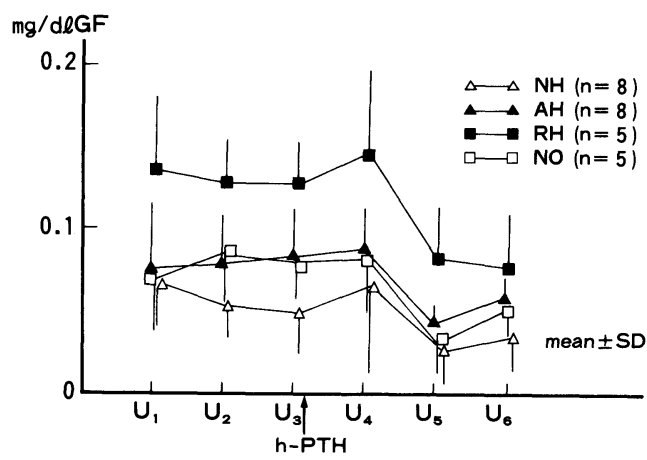

血中，尿中 Cr は Brod and Sirota's 法，尿中 $\mathrm{Ca}$ は EGTA 滴定法, 血中, 尿中 $\mathrm{P}$, 尿中 $\mathrm{Na}$ は autoanalyzer, 血中, 尿中 c-AMP はヤマサキットを用いてラジ オイムノアッセイ法, 血漿 $1,25(\mathrm{OH})_{2} \mathrm{D}$ はヤマサ製 receptor cytosol を用いた radioreceptor assay 法に より測定した ${ }^{11)}$. 各尿中排泄量は GFR 補正で比較検 討した.

結果は mean \pm standard deviation (mean $\pm \mathrm{SD}) て ゙$ 表示し, Students's t testにて有意差検定をした。

\section{結果}

1. 尿中 $\mathrm{Ca}$ 排泄量 $(\mathrm{mg} / \mathrm{dlGF})$ (図 3 )

1-a）h-PTH 負荷前（U1 U13）

尿中 $\mathrm{Ca}$ 排泄量は, $\mathrm{RH}$ 群で他の 3 群より有意に高 值を示したが, NO, NH, AH 群の間には有意差を認 めなかった。

1-b）h-PTH 負荷による変動

h-PTH 負荷後 1 時間尿（U4）の尿中 Ca 排泄量は, 負荷前 (U3) に比へ，個々の症例で様々な変化を呈し， 各群で一定の傾向を認めなかった。負荷後 2 時間尿 (U5) の尿中 Ca 排泄量は, 負荷前 (U3)に比べ, 全て の群で有意に低下した。各群間にはいずれも差を認め なかった。

2. 尿中 $\mathrm{Na}$ 排泄量 $(\mathrm{mEq} / \mathrm{IGF})$ (因 4 )

2-a）h-PTH 負荷前（U1～U3）

尿中 $\mathrm{Na}$ 排泄量は, 各群間に有意差を認めなかった。 2-b）h-PTH 負荷による変動

h-PTH 負荷後 1 時間尿 (U4) の尿中 Na 排泄量は, 負荷前（U3）に比べ著明に上昇した。 また，負荷後 2 時間尿 (U5) では, U3に比べ全ての群で有意に減少し た。各群間にはいずれも差を認めなかった。

3. 尿中 $\mathrm{Ca}$ と尿中 $\mathrm{Na}$ 排泄量の関係

3-a）h-PTH 負荷前（U1～U3）（図 5 ) 
図 4 尿中 $\mathrm{Na}$ 排泄量の変動

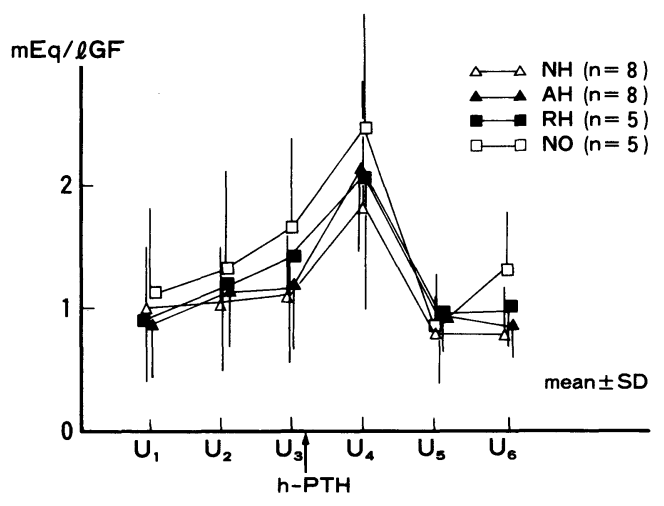

図 5 h-PTH 負荷前 (U3) における尿中 Ca 排泄量と 尿中 $\mathrm{Na}$ 排泄量の関係
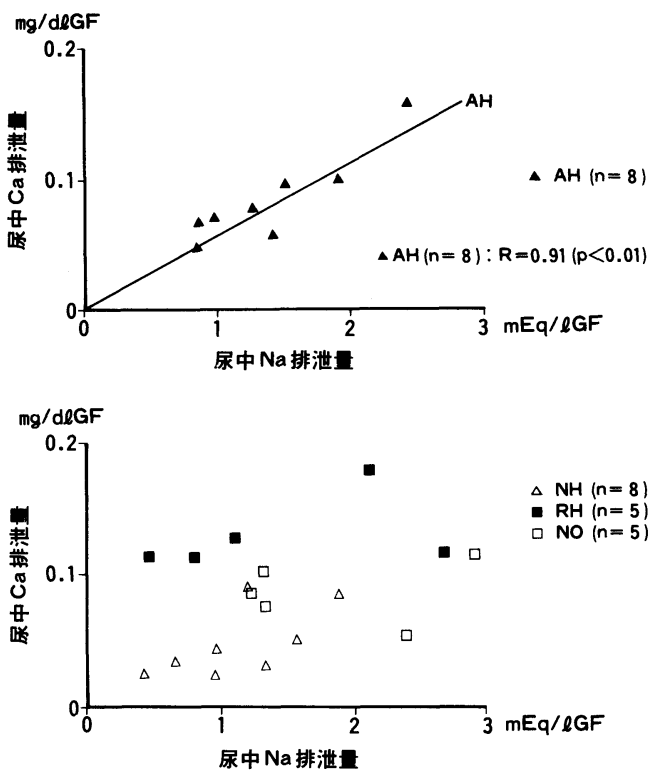

尿中 $\mathrm{Na}$ 排泄量と $\mathrm{Ca}$ 排泄量は, $\mathrm{AH}$ 群の $\mathrm{U} 2, \mathrm{U} 3$ で 有意に正の相関を示したが，他の 3 群では相関を認め なかった。図 5 にはUでの両者の関係を示した。

3-b) h-PTH 負荷による変動

h-PTH 負荷前後 1 時間尿の尿中 Ca 排泄量の増加 率と $\mathrm{Na}$ 排泄量の増加率 $\{(\mathrm{U} 4-\mathrm{U} 3) / \mathrm{U} 3\}$ は, AH 群 でのみ有意に正の相関を示し, 他の群では相関はみら れかかった（図 6 ). 負荷後 2 時間尿の増加率 \{(U5U3)/U3\}でみても, 両者は AH 群でのみ有意に正の相 関を示した。

4. 尿中 $P$ 排泄量 $(m g / d l G F)$ ，血中 $P(m g / d l) ， \%$
図 $6 \mathrm{~h}-\mathrm{PTH}$ 負荷後 1 時間尿での尿中 $\mathrm{Ca}$ と $\mathrm{Na}$ 排 泄量の増加率 (U4-U3)/U3の関係
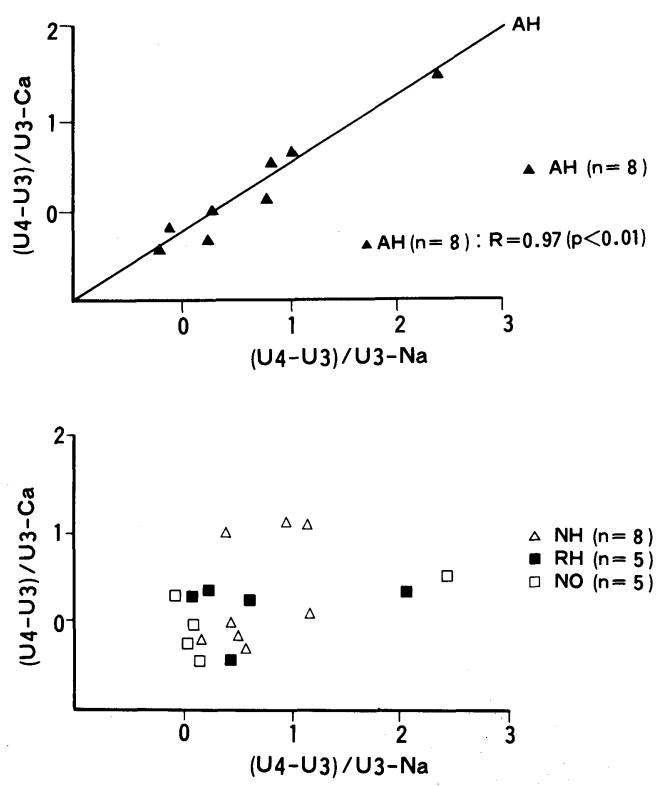

図 7 h-PTH 負荷前（U3）における血中 P 值

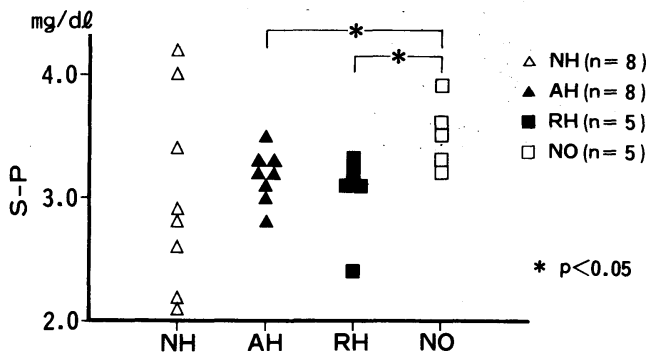

TRP

4-1）h-PTH 負荷前（U1～U3）

尿中 $\mathrm{P}$ 排泄量は各群間に有意差を認めなかった. U3 採取時における血中 $\mathrm{P}$ は $\mathrm{AH}$ 群, $\mathrm{RH}$ 群で $\mathrm{NO}$ 群に比 べ有意に低値であった（図 7 ）。また，U3における\% TRP は RH 群で他群に比べ有意に低値を示したが, 他の 3 群間に有意差を認めなかった(図 8 ).\%TRP と N-c-AMP の間には, 各群とも有意の相関は示さな かった.

4-2）h-PTH 負荷による変動（因 9）

h-PTH 負荷後 1 時間尿（U4）の尿中 P 排泄量は, 負荷前（U3）に比べ著明に上昇した。負荷後 2 時間尿 (U5)では, RH 群の尿中 $\mathrm{P}$ 排泄量は他の 3 群より有意 に高值を示した。 また負荷前の\%TRP と負荷後の尿中 
図 8 h-PTH 負荷前（U3）に打ける\%TRP

(\%)

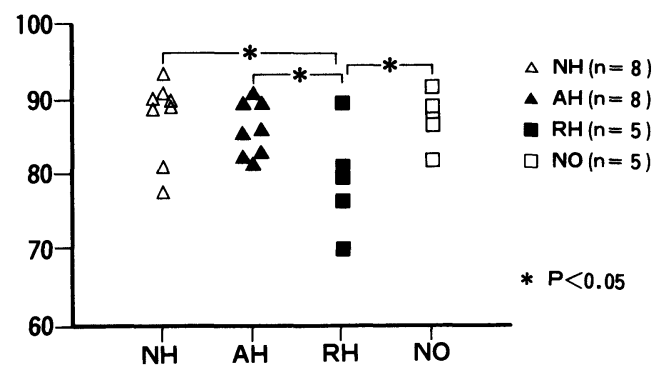

図 9 尿中 $\mathrm{P}$ 排泄量の変動

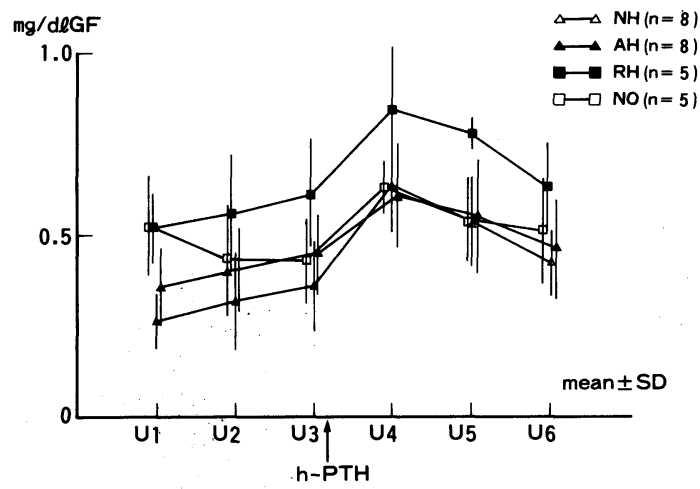

四10 h-PTH 負荷前 (U3) の\%TRP と負荷後の尿中 $\mathrm{P}$ 排泄量の増加率の関係
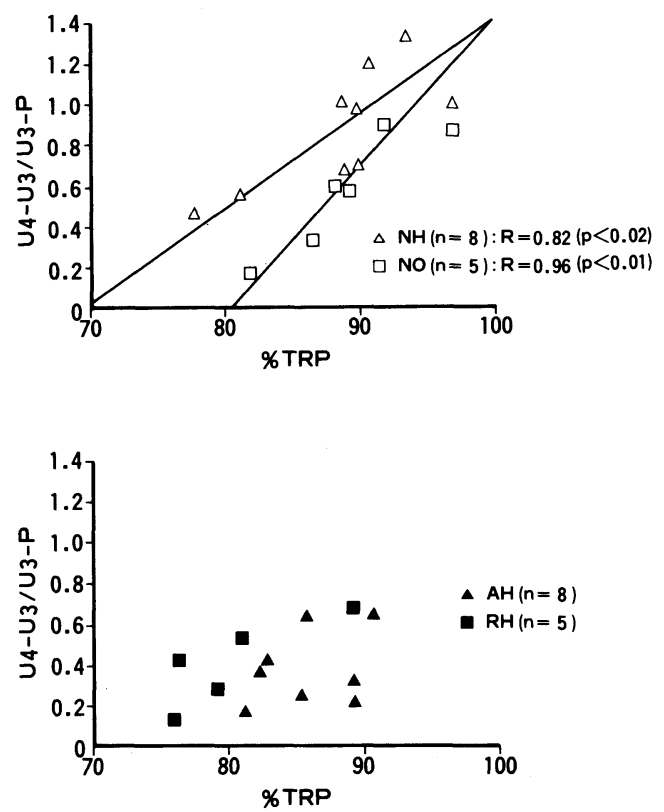

図11 h-PTH 負荷前（U3）における腎原性 c-AMP (N-c-AMP)

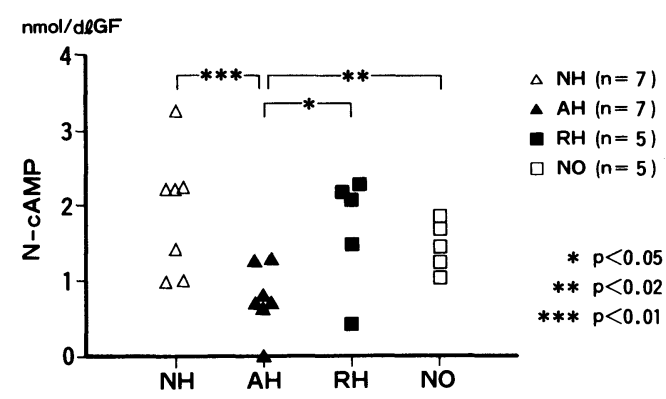

図12a 血中 c-AMP の変動

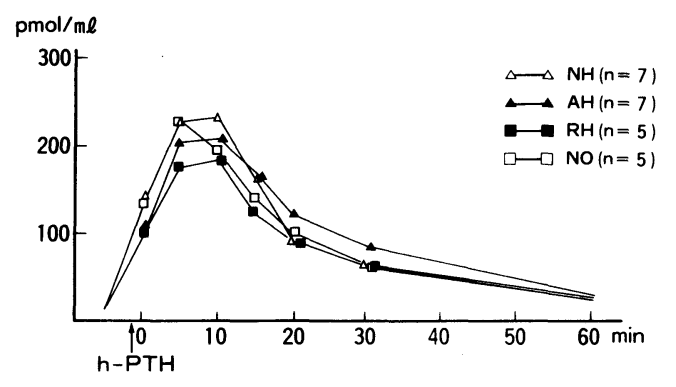

因12b 血中 c-AMP の最大值

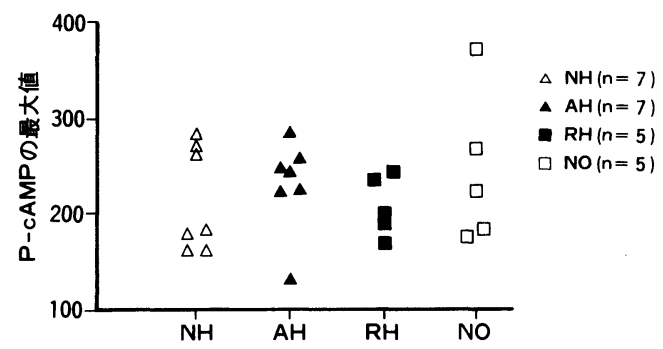

$\mathrm{P}$ 排泄量の増加率 $\{(\mathrm{U} 4-\mathrm{U} 3) / \mathrm{U} 3\}$ は, $\mathrm{NH}$ 群と NO 群で有意の相関を示したが, $\mathrm{AH}$ 群, RH 群では明らか な関係を認めなかった（図10）。なお，負荷前の N-cAMP と負荷後の尿中 P 排泄量の増加率の間には各群 とも有意の相関を認めなかった。

5. 尿中 c-AMP 排泄量 $(\mathrm{nmol} / \mathrm{dlGF})$, 血中 c-AMP $(\mathrm{pmol} / \mathrm{ml}), \quad \mathrm{N}-\mathrm{c}$-AMP $(\mathrm{nmol} / \mathrm{dl})$

5-1）h-PTH 負荷前（U1～U3）

尿中 c-AMP 排泄量は, 各群間に有意差を認めな かった. N-c-AMPは, AH 群で他の 3 群より有意に低 值を示した（図11）が, 他の 3 群間には有意差を認め なかった。 
図13a＼cjkstart尿中 c-AMP 排泄量の変動

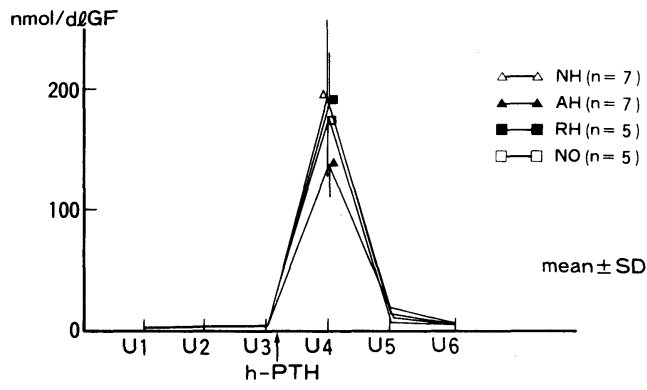

図13b h-PTH 負荷後 1 時間尿 (U4) における尿中 c-AMP 排泄量

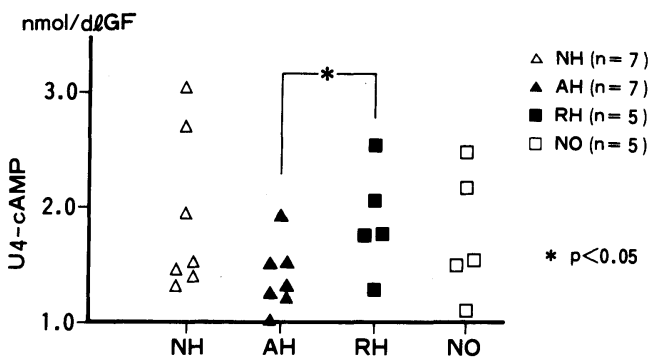

5-2）h-PTH 負荷による変動

5-2-a) 血中 c-AMP（図12a）

血中 c-AMP は, 各群とも h-PTH 負荷後明らかに 上昇し， 5 分 10 分で最大值を示し，負荷後 60 分には 負荷前の值まで低下した。血中 c-AMP の変動, 最大値 では各群間に差を認めなかった（図12b）.

5-2-b）尿中 c-AMP（図13a）

尿中 c-AMP 排泄量は, 各群とも h-PTH 負荷後 1 時間尿（U4）で明らかに上昇した。 NO 群と結石患者 群には有意差を認めなかった。しかし， AH 群では， $\mathrm{RH}$ 群に比べ有意に低値を示した(図13b). h-PTH 負 荷前の N-c-AMP との負荷後の尿中 c-AMP 排泄量の 間には有意の相関を認めなかった。

6. 血漿 $1,25(\mathrm{OH})_{2} \mathrm{D}(\mathrm{pg} / \mathrm{ml})$

6-1）h-PTH 負荷前（U3）（図14a）

血漿 $1,25(\mathrm{OH})_{2} \mathrm{D}$ は， $\mathrm{AH}$ 群で他の群に比べ有意に 高値を示した。

6-2）h-PTH 負荷による変動（図14b）

h-PTH 負荷後，全例で上昇した。 上昇程度，上昇時 間については，明らかな傾向は見られなかった。

\section{考察}

今回の h-PTH 負荷においては E-H 試験に準じた が，E-H 試験自体は，副甲状腺機能低下症での鑑別試 図14a h-PTH 負荷前 (U3) にお抢息漿 $1,25(\mathrm{OH})_{2}$ $\mathrm{D}$ 值

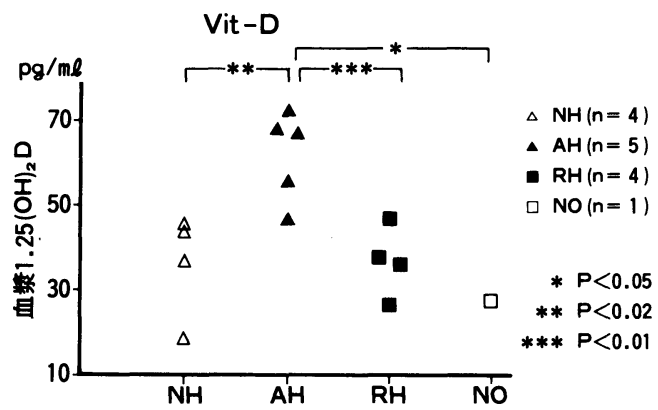

図14b 血漿 $1,25(\mathrm{OH})_{2} \mathrm{D}$ の変動

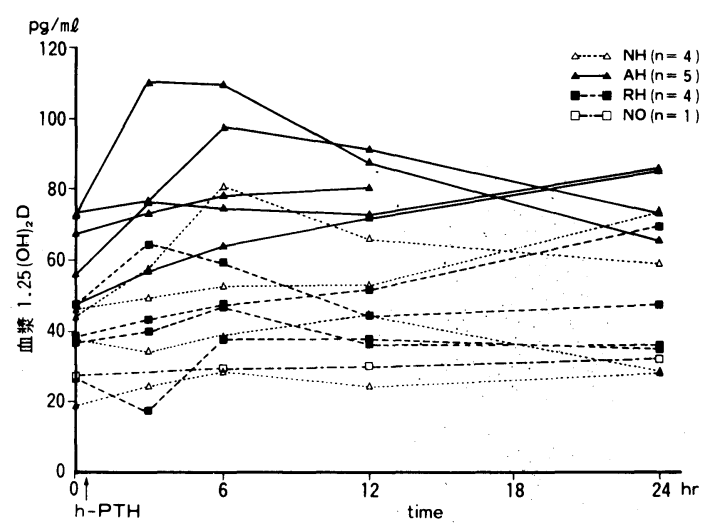

験としてわが国に招いて広く用いられている.しかし， 一般に行われている $\mathrm{E}-\mathrm{H}$ 試験は，尿中 $\mathrm{P}$ 排泄量の変 動に主眼を置いているので尿中 $\mathrm{P}$ 排泄量の変動の少 ない1：00p.m. にh-PTH を負荷してその反応性を検 討している ${ }^{10)}$. 今回は, 尿中 $\mathrm{Ca}$ 排泄量の变動に主目的 を扣き，尿中 $\mathrm{Ca}$ 排泄量に与える食事の影響を出来る だけ少なくするために, over night fasting の状態で施 行し， 10：00a.m. に h-PTH を負荷して比較検討を加 えた。

1. 尿中 $\mathrm{Ca}$ 排泄量

結石患者における PTH 負荷による尿中 Ca 排泄量 の変動については報告が少なく，わずかに，Dunzendorfer 等 ${ }^{12)}$ が，PTE (Parathyroid Extract) 投与後, 結石患者でも正常コントロールと同様に尿中 $\mathrm{Ca}$ 排泄 量が上昇したと報告しているだけである，高 $\mathrm{Ca}$ 㽷症 の有無による反応性について比較検討した報告は検索 した範囲ではみあたらなかった。

今回の検討では, h-PTH 負荷後 1 時間尿の尿中 $\mathrm{Ca}$ 排泄量は，各群とも明らかな傾向を認めなかった。一 
方 PTHは $\mathrm{Na}$ 再吸収を抑制することが知られてお $\eta^{13)}$ ，今回の検討で尿中 $\mathrm{Na}$ 排泄量が負荷後 1 時間尿 で著明に増加したこと, PTH が Na 再吸収を抑制す ること ${ }^{13)}, \mathrm{Ca}$ 再吸収の大部分が遠位尿細管以前の $\mathrm{Na}$ 再吸収に coupling して行われること融を考慮すると， h-PTH 負荷後 1 時間尿の尿中 Ca 排泄量が一定の変 動を示さなかった理由は次のように考えられる，h$\mathrm{PTH}$ 負荷による近位尿細管での $\mathrm{Na}$ 再吸収抑制に伴 い, 同部位での $\mathrm{Ca}$ 再吸収が抑制され, 遠位尿細管に達 する尿中 $\mathrm{Ca}$ 量が増加した結果, h-PTH 直接作用によ る遠位尿細管での $\mathrm{Ca}$ 再吸収が相殺されたためである と考学られた．h.PTH 負荷後 1 時間尿 (U4) での尿中 $\mathrm{Na}$ 排泄量増加に比べ Ca 排泄量増加は明らかに少な く,このことは遠位尿細管での h-PTH による Ca 再吸 収が行われたことを示唆していると考えられた。した がって, 各群に打ける遠位尿細管での $\mathrm{Ca}$ 再吸収機構 には明らかな障害は無いと考学られた。

h-PTH 負荷後 2 時間尿での Ca 排泄量は負荷前に 比べ低下したが, 尿中 $\mathrm{Na}$ 排泄量も著明に低下した。 こ の $\mathrm{Na}$ 排泄量の低下は, 負荷後 1 時間尿での著明な排 泄量の増加に引き続く rebound によるものと推測さ れる.このことがら, 負荷後 2 時間尿の $\mathrm{Ca}$ 排泄量の低 下は, h-PTH 負荷による直接的変化ではなく, 近位尿 細管での $\mathrm{Na}$ 再吸収方進に伴 $\mathrm{Ca}$ 再吸収亢進の結果 であると考兄られた．以上のごとく $\mathrm{PTH}$ 負荷後の尿 中 $\mathrm{Ca}$ 排泄量には尿中 $\mathrm{Na}$ 排泄量が大きく関与してい ることが示唆された。

\section{2. 高 $\mathrm{Ca}$ 尿症の病態}

正常者に打いて, $\mathrm{Na}$ を負荷すると尿中 $\mathrm{Ca}$ 排泄量が 増加することが知られているが14)，尿路結石患者に打 ける尿中 $\mathrm{Ca}$ と尿中 $\mathrm{Na}$ の関係については明らかでな い.

Muldowney 等 ${ }^{15)}$ は, 高 $\mathrm{Ca}$ 尿症の大きな原因は $\mathrm{Na}$ の過利摂取であるとしているが，逆に Coe 等4)は，高 $\mathrm{Ca}$ 尿症の主因として尿中 $\mathrm{Na}$ の影響は少ないとして いる。しかし，いずれの報告も $\mathrm{AH}$ 群， RH 群での違 いについては検討していない。

今回の検討では, h-PTH 負荷前の尿中 $\mathrm{Ca}$ と $\mathrm{Na}$ 排 泄量，拉よび負荷後 1 時間尿， 2 時間尿での両者の増 加率をみると，ともに $\mathrm{AH}$ 群でのみ強い正の相関を示 した。尿中 $\mathrm{Na}$ 排泄量では他の群と差を認めないこと から， $\mathrm{AH}$ 群に打ける尿中 $\mathrm{Ca}$ 排泄量は尿中 $\mathrm{Na}$ 排泄 量に強く影響されていると考えられた。その原因とし ては次のように考兄られた。 AH 群では負荷前での
N-c-AMP が低值を示して括り，副甲状腺機能が抑制 されていると考えられる。したがって遠位尿細管での $\mathrm{Ca}$ 再吸収量が少なくなるため, 近位尿細管に打ける $\mathrm{Na}$ 再吸収抑制に伴う $\mathrm{Ca}$ 再吸収抑制の変化が強調さ れてくると考光られる，以上より，AH群に打ける高 $\mathrm{Ca}$ 尿症の一因として尿中 $\mathrm{Na}$ 排泄量の増加に上る二 次的影響は無視できないものと考兄られた。

$\mathrm{RH}$ 群では，他の群に比べ負荷前の尿中 Ca 排泄量 が, 尿中 $\mathrm{Na}$ 排泄量に関係なく高値を示し, $\mathrm{RH}$ 群にお ける Ca 排泄量の増加は, $\mathrm{Ca}$ 漏出にあることが示唆さ れた。 また, 既述したように遠位尿細管での $\mathrm{Ca}$ 再吸収 機構に障害の無いことが示唆されることから, Ca 漏出 の原因は Sakhaee 等 ${ }^{16)}$ が言らように近位尿細管にあ ると考兄られた。この様に, 空腹時における尿中 $\mathrm{Ca}$ 排 泄量と尿中 $\mathrm{Na}$ 排泄量の関係をみると, $\mathrm{AH}$ 群では Muldowney 等の報告 ${ }^{15)}$ を, RH 群では Coe 等の報告(4) を支持する結果が得られたことは興味深い。

次に尿中 $\mathrm{P}$ 排泄量について検討してみたい。まず, 各群に打ける負荷前の\%TRP と N-c-AMP の間に相 関関係を認めなかったことから，今回の測定範囲で は, \%TRP が必ずしも副甲状腺機能を反映していない ことが示唆された。また, NO 群, NH 群において PTH 負荷後の尿中 P 排泄量の増加率と負荷前の\%TRP と 有意の相関を示したが，負荷前の N-c-AMP とは明ら かな関係を認めなかった。したがって, h-PTH 負荷後 の尿中 P 排泄量の増加率は負荷前の\%TRP の値の影 響が大きいと考えられる。しかし, $\mathrm{AH}$ 群, RH 群では, 尿中 P 排泄量の増加率と\%TRP の間に有意の相関を 認めなかった。この結果は, NH 群で有意の相関を示 したことを考慮すると，少なくとも結石による尿細管 障害などの二次的影響によるものではなく，高 $\mathrm{Ca}$ 尿 症に扮ける P の h-PTH 反応性に障害があるためと考 えられた。

さらに各群についてみると, $\mathrm{AH}$ 群では, $\mathrm{NO}$ 群 $\mathrm{NH}$ 群に比べ basal period での血中 P が低值を, 血漿1, $25(\mathrm{OH})_{2} \mathrm{D}$ が高值を, N-c-AMP が低值を示した。 これ は，尿細管における $\mathrm{P}$ 漏出のために $1,25(\mathrm{OH})_{2} \mathrm{D}$ の活 性化が六進し, 二次的に副甲状腺機能が抑制された結 果であり，Pの一次的な漏出を示唆するものと考兄ら れた。

RH 群では, h-PTH 負荷前において\%TRP が低值 を示したが,一般に\%TRPが低值を示す原因として副 甲状腺機能の充進あるいは尿細管の機能障害が考えら れている ${ }^{16)}$. 今回の検討では負荷前での N-c-AMP が 
高値を示していないにもかかわらず，血中 P が低值で あったことから尿細管機能障害によるものと考えられ た。既述したようにPの h-PTH 反応性に障害がある ことを考光合わせると，AH 群同様 RH 群においても $\mathrm{P}$ の漏出が存在すると考光られた。 $\mathrm{AH}$ 群と異なり $\mathrm{P}$ の漏出があるにもかかわらず $1,25(\mathrm{OH})_{2} \mathrm{D}$ 活性化の克 進と副甲状腺機能の抑制を認めなかったのは，同時に $\mathrm{Ca}$ 漏出があるために副甲状腺機能が刺激され, 結果的 に副甲状腺機能の抑制がおきないと推測された。すな わち, $\mathrm{RH}$ 群の副甲状腺機能 と $1,25(\mathrm{OH})_{2} \mathrm{D}$ の活性化 は $\mathrm{P}$ 漏出と $\mathrm{Ca}$ 漏出のバランスにより決定されている ものと考光られた。

以上ををとめると，高 $\mathrm{Ca}$ 尿症には一次的な $\mathrm{P}$ の漏 出があり，これに様々な程度の $\mathrm{Ca}$ 漏出が加わること により, $\mathrm{AH}$ 群から $\mathrm{RH}$ 群まで連続的な病態が存在す ると考兄られた。この仮説は，一般に $\mathrm{AH}$ 群と $\mathrm{RH}$ 群 の間の尿中 Ca 排泄量, N-c-AMP 等に連続性が認めら れる事, 経口 $\mathrm{Ca}$ 負荷試験で $\mathrm{AH}$ 群と $\mathrm{RH}$ 群の mixed type (空腹時尿中 $\mathrm{Ca}$ 排泄量, 及び経口 $\mathrm{Ca}$ 負荷後の尿 中 Ca 排泄量の増加がともに異常) が存在することを 矛盾無く説明することができる。しかし，今回対象と した RH 群では負荷前での副甲状腺機能の克進を認 めず, Sakhaee 等 ${ }^{16)}$ の分類する FH 群 (Fasting hypercalciuria）に近い病態とも考えられ，明らかな副甲状 腺機能の亢進を伴う $\mathrm{RH}$ 群についてはさらに検討が 必要である。

$\mathrm{NH}$ 群では, h-PTH 負荷前の\%TRP にばらつきが 大きいが，尿中 $\mathrm{P}$ 排泄量の変動，及び増加率等におい て明らかな障害を認めなかったことから,h-PTH に対 するPの反応性に障害はないと考兄られた。

3. 尿中 c-AMP 排泄量, 血 中 c-AMP, 血漿 1 , $25(\mathrm{OH})_{2}$ の変動

既述したような各群での負荷前における副甲状腺機 能状態の違いを考慮すると, 尿中, 血中 c-AMP, 血漿 $1,25(\mathrm{OH})_{2} \mathrm{D}$ に何等かの違いがあると予想された。し かし, h-PTH 負荷後の尿中 c-AMP 排泄量, 血中 cAMP は，負荷前の N-c-AMP，あるいは尿中 c-AMP 排泄量と有意の相関を認めず，今回の h-PTH 負荷の 方法では, 負荷前の副甲状腺機能と h-PTH 反応性の 間には明らかな因果関係は見出だせなかった。その理 由としては, 各群に扮ける負荷前の副甲状腺機能が正 常域にあったためと推測している。 また，尿中 c-AMP 排泄量, 血中 c-AMP, 血漿 $1,25(\mathrm{OH})_{2} \mathrm{D}$ の変動では, NO 群を含めて各群に特徵的所見を認めず, 各群での
h-PTH 反応性には明らかな障害はないことが示唆さ れた。これらのことから，各群の副甲状腺機能は各病 態に対して正常に反応していることが推測される。し かしながら, 内分泌学的に明らかな異常のない症例, 特に結石患者に打いてc-AMP の変動から h-PTH 反 応性をみた報告がないこと，さらに血漿 $1,25(\mathrm{OH})_{2} \mathrm{D}$ の h-PTH 反応性自体が未だ不明である事などから， これらの PTH 反応性に関しては今後の検討課題と思 われる。 また, 今回の検討では NO 群の性, 年齢のマッ チングについては考慮しなかったので，性差，年齢差 についてはなお検討する必要があるかもしれない。

\section{結 語}

$\mathrm{Ca}$ 含有結石患者を正常 $\mathrm{Ca}$ 尿症 ( $\mathrm{NH}$ 群)，腸管吸収 型高 $\mathrm{Ca}$ 㽷症 ( $\mathrm{AH}$ 群), 腎漏出型高 $\mathrm{Ca}$ 㽷症 ( $\mathrm{RH}$ 群) に分類した後，ヒト副甲状腺ホルモン（h-PTH）を負 荷し，その反応性から各群の病態について加えた。な お対照として正常者 (NO 群) 飞も同様の負荷試験を施 行した.

(各物質の変動)

h-PTH 負荷後の尿中 Ca 排泄量は一定の傾向を認 めず，尿中 $\mathrm{Na}$ 排泄量の変動による二次的な影響を受 けると考兄られた，尿中 P 排泄量は h-PTH 負荷後明 らかに増加し，h-PTH 負荷前（U3）の\%TRP と負荷 後 1 時間での尿中 $\mathrm{P}$ 排泄量の増加率 $\{(\mathrm{U} 4-\mathrm{U} 3) / \mathrm{U} 3\}$ は NO 群, NH 群で正の相関を示した. 血中 c-AMP は h-PTH 負荷後 $5 \sim 10$ 分で最大值に達し, 血漿1, $25(\mathrm{OH}){ }_{2} \mathrm{D}$ も負荷後上昇したが各群に違いを認めな かった.

\section{(各群の検討)}

1. NH 群では, h-PTH 負荷前後の尿中排泄量の変 動は NO 群と明らかな違いがなく, h-PTH 反応性に 異常を認めなかった。

2. $\mathrm{AH}$ 群では, 尿中 $\mathrm{Ca}$ 排泄量の変動は尿中 $\mathrm{Na}$ 排 泄量の影響を特に強く受け, 高 $\mathrm{Ca}$ 尿症の一因として 尿中 $\mathrm{Na}$ 排泄量による影響は無視できないと考兄られ た。 また，h-PTH 負荷前 (U3) の\%TRP と負荷後 1 時間尿の増加率 $\{(\mathrm{U} 4-\mathrm{U} 3) / \mathrm{U} 3\}$ では, $\mathrm{NO}$ 群, $\mathrm{NH}$ 群と異なり, 高 $\mathrm{Ca}$ 尿症 ( $\mathrm{AH}$ 群, $\mathrm{RH}$ 群) では明らか な関係を認めず，Pの h-PTH 反応性に障害があると 考兄られた. 血中 $\mathrm{P}$ が低值を示すこと, 血漿 $1,25(\mathrm{OH})_{2}$ D が高値を示すこと， N-c-AMP が低值を示すこと等 から，一次的な $\mathrm{P}$ の漏出があると考学られた。

3. RH 群では, $\mathrm{Na}$ 排泄量に関係なく尿中 $\mathrm{Ca}$ 排泄 量が高值を示し, Ca の漏出が示唆された。また，Pの 
h-PTH 反応性に障害があること，血中 P が低值で\% TRP も低值を示すことから, AH 群同様の P の漏出 が示唆された。しかし, AH 群と異なり, 血漿1, $25(\mathrm{OH}){ }_{2} \mathrm{D}$ が高值を示さず， N-c-AMP が低值を示さ ないことから， RH 群の副甲状腺機能と $1,25(\mathrm{OH})_{2} \mathrm{D}$ 活性化は $\mathrm{P}$ 漏出だけでなく $\mathrm{Ca}$ 漏出とのバランスによ り決定されている可能性が考兄られた。

4. 高 $\mathrm{Ca}$ 尿症の原因は一次的な $\mathrm{P}$ の漏出が根本で あり, $\mathrm{Ca}$ の漏出の程度により $\mathrm{AH}$ 群から $\mathrm{RH}$ 群まで 連続的な病態が存在していると考兄られた。

$$
\text { 文献 }
$$

1) Broadus, A.E., Dominguez, M. and Bartter, F. C.: Pathophysiological studies in idiopathic hypercalciuria: Use of an oral calcium tolerance test to characterize distintive hypercalciuric subfroups. J. Clin. Endocriol. Wetab., 47, 751-760, 1973.

2) Annoym.: Pathogenesis of idiopathic hyperacalciuria. Lancet, I, 1001-1002, 1984.

3) Evans, R.A., Hills, E., Wong, S.Y.P., Wyndham, L.E., Eade, Y. and Dunstan, C.R.: The pathogenesis of idiopathic hypercalciuria : Evidence for hyperparathyroid hyperfunction. Q.J. Med., 209, 41-53, 1984.

4) Coe, F.L. and Parks, J.H.: Familial (Idiopathic) hypercalciuria in nephrolithiasis: Pathgenesis and Treatment. Year Book Med. I.N.C., Chicago. London. Bocaration, 2nd. ed., p. 106 $-138,1988$.

5) Pak, C.Y.C., Chata, M., Lawrence, E.C. and Synder, W.: The hypercalciurias : Causes, parathyroid functions and diagnostic criteria. J. Clin. Invest., 54, 387-400, 1974.

6) Pak, C.Y.C., Britoon, F., Peterson, R., Ward, D., Northcutt, C., Breslau, N.A., Mcguire, J., Sakhaee, K., Bush, S., Nicar, M., Norman, D.A. and Peters, P.: Amburatory evaluation of nephrolithiasis: Classification, clinical presentation and diagnostic criteria. Am. J. Med., 69, 19-30, 1980.

7) Kaplan, R.A., Haussler, M.R., Deftos, L.J., Bone, H. and Pak, C.Y.C.: The role of $1 \alpha$, 25-dihydroxyvitamin $\mathrm{D}$ in the medication of intestinal hyperabsorption of calcium in primary hyperparathyroidism and absorptive hypercalciuria. J. Clin. Invest., 59, 756-760, 1977.

8) Bordier, P., Psckewart, A., Gueris, J. and Rasmussen, H.: On the pathogenesis of so-called idiopathic hypercalciuria. Am. J. Med., 63, 398-409, 1977.

9）棌 孝義：特発性高 $\mathrm{Ca}$ 尿症の病型分類と鑑別診 断。ホルモンと臨床，34，1003-1007， 1986.

10）尾形悦郎, 藤田拓男, 古川洋太郎：ヒト PTH (1 -34）による Ellsworth-Howard 試験の実施法と 判定基準. 日内分泌会誌，60，971-984，1984.

11) Mizunashi, K., Furukawa, Y., Sohn, H., Miura, R., Yumita, S. and Yoshinaga, K.: Heterogeneity of pseudohypoparathyroidisum type I from the aspect of urinary excretion of calcium and serum levels of parathyroid hormone. Calcif. Tissue Int., 46, 227-232, 1990.

12) Dunzendorfer, U. and Knoner, M.: Effects of high level bovine parathyroid extracts on serum PTH, cAMP and urinary cAMP, $\mathrm{Na}, \mathrm{K}$ and Uric acid in stone-forming patients. Eur. Urol., 8, 363-366, 1982.

13) Maxwell, M.H. and Kleeman, C.R., 編 : 二価1 オン恒常性維持機構一 $\mathrm{Ca}, \mathrm{P}, \mathrm{Mg}$ ならびに骨の生 理と代謝. 水電解質代謝の臨床, p. 321-470, 中 外医学社, 1984 .

14) McCarron, D.A., Rankin, L.I., Bennett, W.M., Krutzik, S., McCtung, M.R. and Luft, F.C.: Urinary calcium excretion at extremes of sodium intake in normal men. Am. J. Nephrol., 1, 84-90, 1981.

15) Muldowney, F.P., Freaney, R. and Moloney, M. F. : Importance of dietary sodium in the hypercalciuria syndrom. Kid. Int., 22, 292-296, 1982.

16) Sakhaee, K., Nicar, M.J., Brater, C. and Pak, C. Y.C. : Exaggerated natriuric and calciuric responsesto hydrochlorothiazied in renal hypercalciuria but not in absorptive hypercalciuria. J. Clun. Endocrinol. Metab., 61, 825-829, 1985. (1992年 1 月 9 日受理) 